\title{
PERAN LEMAK EPIKARDIAL PADA PENYAKIT JANTUNG KORONER STABIL
}

\author{
Ulzim Fajar' ${ }^{1)}$, Mefri Yanni ${ }^{2)}$ \\ ${ }^{1}$ Ilmu Penyakit Jantung dan Pembuluh Darah, Fakultas Kedoktaran, Universitas Andalas \\ email: ulzimparsel@gmail.com \\ ${ }^{2}$ Ilmu Penyakit Jantung dan Pembuluh Darah, Fakultas Kedoktaran, Universitas Andalas
}

Submitted: 10-04-2020,Reviewer: 11-04-2020,Accepted: 20-04-2020

\begin{abstract}
Visceral fat tissue widely known have endocrine function by secreting Cytokines that provide it function in metabolism of visceral organ such as heart. It function have pivotal role under physiology and patology condition by secreting antiinflamatory cytokines in physiology condition, otherwise proinflammatory cytokines in patology condition. Epicardial fat tissue as regard this function, have more important role to the heart, because it have two advantage than other visceral depots. First, this tissue have same microcirculation provided by small branch of coronary arteries, and second it were not boundary by any structure. Recent studies found that there were correlation between increased epicardial fat depot and coronary artery disease. It seems correlate with this unique structure and function. This literature review focuse on how is the role of epicardial fat tissue in atheroschlerotic process especially in coronary artery.
\end{abstract}

Keywords: Epicardial fat, coronary artery disease.

\begin{abstract}
Abstrak
Jaringan lemak viseral sudah dikenal luas mensekresikan sitokin-sitokin yang berperan pada fungsi serta metabolisme organ viseral termasuk jantung. Jaringan lemak epikardial mempunyai kelebihan yang membedakannya dengan depot jaringan lemak viseral lain. Hal ini karena kedekatan fungsional serta anatomi antara lemak epikardial dan jantung. Pertama, kedua jaringan ini berbagi aliran darah yang sama dari arteri koroner, selanjutnya tidak ada struktur pembatas antara jaringan lemak epikardial, miokard, dan arteri koroner. Peningkatan kuantitas lemak epikardial dari penelitian yang ada berhubungan dengan peningkatan resiko penyakit jantung iskemik. Masa lemak epikardial lebih kecil dibandingkan dengan depot lemak lainnya. Akan tetapi kedekatan anatomi dari jaringan ini terhadap jantung menjadi dasar teori bahwa adipokin yang dihasilkan oleh jaringan lemak epikardial lebih memiliki efek yang kuat terhadap jantung dan pembuluh darah koroner itu sendiri. Tinjauan pustaka ini difokuskan pada peran dari lemak epikardial terhadap proses aterosklerosis koroner.
\end{abstract}

Kata kunci : Lemak epikardial, penyakit jantung koroner

\section{PENDAHULUAN}

Penyakit jantung koroner (PJK) masih merupakan salah satu masalah terbesar dalam kesehatan dunia. World Health Organization (WHO) pada tahun 2008 menyebutkan bahwa penyakit jantung iskemik bertanggung jawab pada lebih dari 7 juta $(12,8 \%)$ kematian di seluruh dunia. Hasil Riset Kesehatan Dasar
(Riskesdas) 2013 menunjukkan penyakit jantung koroner berada pada posisi ketujuh tertinggi diantara penyakit tidak menular di Indonesia. Menurut data WHO, diperkirakan kematian akibat PJK di Indonesia mencapai 17,5\% dari total kematian di Indonesia. ${ }^{1,2}$

Beberapa penelitian sudah menunjukkan bahwa obesitas sentral lebih berpengaruh pada sindroma metabolik dan penyakit 
kardiovaskular, salah satunya adalah penelitian oleh Prasetya M dkk pada tahun 2015, yang menemukan bahwa lingkar perut abnormal sebagai cerminan obesitas sentral berhubungan dengan kadar Low density Lipoprotein yang tinggi pada pasien dengan penyakit jantung koroner dengan odd ratio 2.64 daripada hanya sekedar index masa tubuh (IMT). ${ }^{3}$ Penelitian Framingham tahun 2011 telah membuktikan bahwa volume lemak viseral abdomen yang dinilai melalui Computed tomography merupakan faktor resiko dependen dan berkorelasi terhadap gangguan kardiometabolik dan penyakit kardiovaskular. ${ }^{3}$ Peningkatan Lemak viseral abdomen pada penderita penyakit kardiovaskular berhubungan dengan pelepasan mediator-mediator inflamasi oleh sel lemak viseral dan dilepaskan kedalam sirkulasi sistemik. Kondisi ini memulai terjadinya aterosklerosis.

Dalam lebih satu dekade terakhir, peran lemak epikardial dalam proses aterosklerosis khususnya pada arteri koroner mendapat perhatian. Jaringan lemak epikardial penderita penyakit jantung koroner ternyata ditemukan pula mediator inflamasi (Interleukin-6, TNF- $\alpha$, interleukin-1 $\beta$, monocyte chemoattract ant protein-1 (MCP-1)), makrofag, limfosit dan basofil. Mediator ini lebih tinggi dibandingkan jaringan lemak subkutan. Peran inflamasi dari jaringan lemak epikardial yang serupa dengan lemak viseral ini didukung bukti embriologi bahwa lemak viseral abdomen dan lemak epikardial memiliki kesamaan asal sel mesoderm, sehingga memperkuat teori bahwa jaringan lemak epikardial dan lemak viseral ini mempunyai karakteristik yang sama. Namun lemak epikardial memiliki kelebihan karena kedekatan struktur dengan arteri koroner yakni berkontak langsung dan berbagi mikrosirkulasi dari cabang kecil arteri koroner. Temuan diatas mengarahkan keilmuan saat ini bahwa lemak epikardial mungkin mempunyai peran yang lebih dibandingkan lemak viseral dalam proses aterosklerosis arteri koroner. ${ }^{4}$

\section{PEMBAGIAN JARINGAN LEMAK}

Jaringan lemak berdasarkan fungsi terbagi menjadi 2 yaitu:

\section{Jaringan lemak putih}

Kelompok ini terbagi menjadi 2 kelompok:

a. Jaringan lemak viseral, Jaringan lemak yang tersebar di organ-organ dalam, contoh: jaringan lemak epikardial, omental, mesenterika, mediastinal, perivaskular. Fungsi utama dari jaringan lemak ini adalah sebagai fungsi pelepasan berbagai hormone (endokrin), adipokin, dan sitokin.

b. Jaringan lemak subkutan, Berlokasi di subkutan, fungsi utama sebagai penyimpanan energi. Energi disimpan dalam sel lemak dalam bentuk trigliserida dan menyediakan asam lemak bebas sebagai sumber energi, terutama pada kondisi puasa, kelaparan atau olahraga.

\section{Jaringan lemak cokelat}

Berfungsi sebagai termoregulator non mekanik, berhubungan dengan uncoupling protein-1 (UCP-1), suatu protein yang berhubungan dengan fungsi untuk memproduksi panas. $^{5,6}$

\section{JARINGAN LEMAK EPIKARDIAL Anatomi jaringan lemak sekitar jantung}

Jaringan lemak epikardial adalah bagian dari jaringan lemak viseral yang berlokasi antara perikardium viseral dan miokardium, menyelimuti sekitar $80 \%$ permukaan jantung dan merupakan $20 \%$ dari total berat jantung (gambar 1). ${ }^{4,5}$

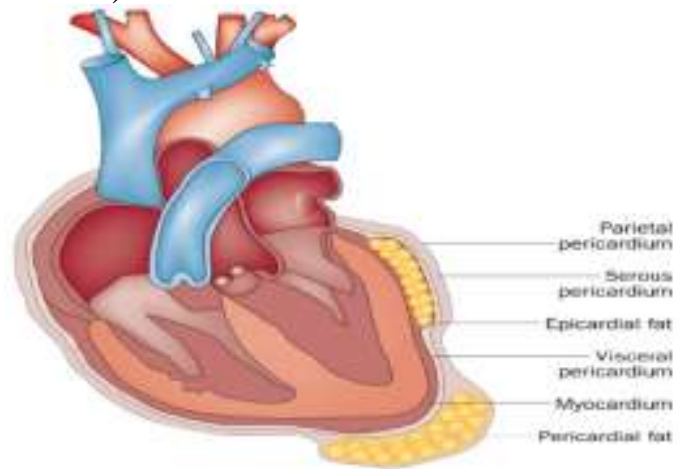

Gambar 1 Sketsa posisi lemak epikardial dan perikardial (Rietdorf K et al) ${ }^{7}$ 
Selain lemak epikardial, ada terminologi lain lemak yang berada disekitar jantung (table 1).

Tabel 1 Terminologi kompartemen lemak sekitar jantung (Nagy E et al) ${ }^{4}$

\begin{tabular}{|c|c|}
\hline $\begin{array}{l}\text { Lemak } \\
\text { viseral }\end{array}$ & $\begin{array}{l}\text { Jaringan lemak pada sekitar } \\
\text { organ-organ viseral }\end{array}$ \\
\hline $\begin{array}{l}\text { Lemak } \\
\text { epikardial }\end{array}$ & $\begin{array}{l}\text { Jaringan lemak viseral antara } \\
\text { permukaan miokardium dan } \\
\text { perikardial visceral }\end{array}$ \\
\hline $\begin{array}{r}\text { Lemak } \\
\text { perikardial }\end{array}$ & $\begin{array}{l}\text { Jaringan lemak antara dua } \\
\text { lapisan perikardial } \\
\text { viseral dan parietal) }\end{array}$ \\
\hline $\begin{array}{r}\text { Lemak } \\
\text { Parakardial }\end{array}$ & $\begin{array}{l}\text { Deposit lemak pada bagian } \\
\text { luar perikardial parietal (lemak } \\
\text { intratorakal ekstra perikardial) }\end{array}$ \\
\hline $\begin{array}{l}\text { Lemak } \\
\text { ektopik }\end{array}$ & $\begin{array}{l}\text { Deposit lemak (trigliserida) } \\
\text { pada jaringan non lemak (seperti } \\
\text { miokardium, hati, pancreas, dan } \\
\text { lain sebagainya) }\end{array}$ \\
\hline
\end{tabular}

Perbedaan antara lemak epikardial dan lemak perikardial penting untuk diketahui. Dari aspek embriologi, lemak epikardial mempunyai embriologi yang sama dengan lemak viseral yaitu berasal dari sel-sel mesodermal, sementara lemak perikardial berasal dari sel ektodermal yang sama dengan asal lemak subkutan. Selain itu, terdapat perbedaan pasokan darah antara kedua jaringan ini. Lemak epikardial diperdarahi oleh cabang-cabang kecil arteri koroner, sementara sirkulasi lemak perikardial diperdarahi oleh pembuluh darah non koroner (cabang dari arteri mamaria interna. $^{4}$

\section{Ciri khas jaringan lemak epikardial}

a) Ukuran sel lemak yang lebih kecil

Sel lemak pada jaringan lemak epikardial lebih banyak disusun oleh sel lemak muda (preadiposit) dari pada sel lemak matang (adiposit matur). ${ }^{5}$ Preadiposit mempunyai ukuran yang lebih kecil dan mempunyai fenotipe endokrin yang lebih dominan dibandingkan sel adiposit matang, termasuk kapasitas mensekresikan mediator inflamasi seperti Tumor Necrosis Factor- $\alpha$
(TNF- $\alpha$ ), Macrophag Cemoattractant Protein-1 (MCP-1), Interleukin-6 (IL-6), dan lain-lain. Selain itu, preadiposit ini berperan dalam rekruitmen sel-sel imun dan sekresi adipokin proinflamasi setelah terpapar dengan asam lemak. Secara invitro preadiposit berespon dengan asam lemak jenuh dan asam lemak tidak jenuh tunggal dengan cara mensekresikan MCP-1, suatu sitokin proinflamasi yang berperan dalam rekruitmen makrofag. ${ }^{8}$

b) Metabolisme asam lemak yang tinggi

Pada lemak epikardial terdapat penggunaan glukosa yang lebih rendah dibandingkan jaringan lemak intraabdomen, metabolisme asam lemak (sintesis, pelepasan, pemecahan) yang lebih tinggi dibandingkan jaringan lemak dilokasi lain, dan efek semakin meningkat dengan respon terhadap ketekolamin (penelitian pada jaringan lemak porsin). ${ }^{5}$ Dari penelitian pada babi, didapatkan pelepasan asam lemak dari jaringan lemak epikardial dua kali lebih tinggi daripada di jaringan lemak perirenal. ${ }^{9}$

c) Struktur yang dekat dengan sel miokardium dan pembuluh darah koroner

Jaringan lemak epikardial menyelimuti miokard dan pembuluh darah koroner secara langsung. Dari potongan histologi tidak ada lapisan pembatas yang memisahkan JLE dengan ke dua struktur tersebut. Kedekatan antara JLE dan sel miokardium menunjang fungsi metabolik dan endokrin dari sel lemak itu sendiri terhadap sel miokard.

d) Embriologi

struktur lemak epikardial dan lemak viseral perut berasal dari jaringan yang sama yaitu mesoderm splanchinopleuric. Sehingga kedua jaringan ini memiliki fungsi yang hampir sama yang dominan sebagai sekretori adipokin.

\section{Fungsi sekresi jaringan lemak epikardial}

Lemak epikardial memproduksi berbagai macam sitokin. Sitokin ini berperan dalam regulasi fungsi endothelial, koagulasi, dan 
inflamasi. Dalam kondisi fisiologis, sel lemak epikardial menghasilkan sitokinsitokin antiinflamasi dan antiaterosklerotik, seperti adiponektin dan adrenomedulin. Adiponektin hanya diproduksi oleh sel lemak viseral dan memiliki efek antidiabetik, antiaterogenik, antioksidatif, dan antiinflamasi. Adiponektin mengaktifasi jalur adenosine monophosphate-activated proterin kinase (AMPK), menyebabkan peningkatan oksidasi asam lemak dan mengurangi deposit lemak pada kardiomiosit. Berbeda dengan adiponektin, adrenomedulin diproduksi oleh berbagai organ yaitu ginjal, paru, dan jantung. Adrenomedulin mempunyai banyak efek kardioprotektif termasuk vasodilatasi, natriuresis, antiapoptosis, dan menstimulasi produksi nitric oxide. ${ }^{10,11}$ Namun pada kondisi patologis, jaringan lemak dapat mensekresikan sitokin proinflamasi, seperti rangkuman pada tabel 2 di bawah ini.

Tabel 2 Molekul bioaktif jaringan lemak epikardial (Iacobellis G et al) ${ }^{12}$

\begin{tabular}{|c|c|}
\hline $\begin{array}{l}\text { Proinflamatorik, } \\
\text { proaterogenik }\end{array}$ & $\begin{array}{l}\text { Antiinflamatorik, } \\
\text { antiaterogenik }\end{array}$ \\
\hline $\begin{array}{l}\text { TNF- } \alpha \\
\text { MCP-1 }\end{array}$ & $\begin{array}{l}\text { Adiponektin } \\
\text { Adrenomedulin }\end{array}$ \\
\hline $\begin{array}{l}\text { IL1, IL1 } \beta, \text { IL- } \\
\text { 1Ra, IL6, IL8, IL10 } \\
\text { CRP, PAI-1 } \\
\text { Prostaglandin } \quad \text { D. } \\
\text { haptoglobin, a 1- } \\
\text { glycoprotein, JNK } \\
\text { sPLA2-IIA, fatty acid } \\
\text { binding protein } 4 \\
\text { RANTES, ICAM }\end{array}$ & \\
\hline \begin{tabular}{lr}
\multicolumn{2}{c}{ Insulin-mimetic, } \\
penanda lemak \\
visceral
\end{tabular} & Termogenik \\
\hline $\begin{array}{l}\text { Resistin } \\
\text { Visfatin } \\
\text { Omentin }\end{array}$ & UCP-1 \\
\hline Growth Factors & $\begin{array}{lr}\text { Faktor } & \text { transkripsi } \\
\text { diferensiasi } & \text { lemak } \\
\text { cokelat } & \\
\end{array}$ \\
\hline $\begin{array}{l}\text { NGF } \\
\text { FLT1 }\end{array}$ & $\begin{array}{l}\text { PRDM16 } \\
\text { PGC-1 } \alpha\end{array}$ \\
\hline $\begin{array}{l}\text { Remodeling } \\
\text { vascular, } \quad \text { kontrol }\end{array}$ & \\
\hline
\end{tabular}

\begin{tabular}{l|l}
\hline $\begin{array}{l}\text { tekanan darah, } \\
\text { hipertrofi miokardial, } \\
\text { adipogenesis }\end{array}$ & \\
\hline \multicolumn{1}{c|}{ Angiotensin, } & \\
angiotensinogen, \\
leptin
\end{tabular}

Keterangan: CRP, C-reactive protein; FLT1, soluble vascular endothelial growth factor receptor; GLUT-4, glucose transporter-4; ICAM, soluble intercellular adhesion molecule; IL, interleukin; IL$1 \mathrm{Ra}$, interleukin-1 receptor antagonist; JNK, c-Jun Nterminal kinase; MCP-1, monocyte chemoattractant protein-1; NGF, nerve growth factor; PAI-1, plasminogen activator inhibitor-1; PGC-1a, PPAR-g coactivator-1a; sPLA2-IIA, secretory type II phospholipase A2; PPAR-g, peroxisomeproliferatoractivated receptor g; PRDM16, brown adipocyte differentiation transcription factor PR-domainmissing16; RANTES, regulated upon activation normal $\mathrm{T}$ cell and secreted; TLRs, toll-like receptors; TNF-a, tumor necrosis factoralpha; UCP1, uncoupling protein-1.

Keunikan dari jaringan lemak epikardial secara anatomi dan fungsi tersebut diatas,

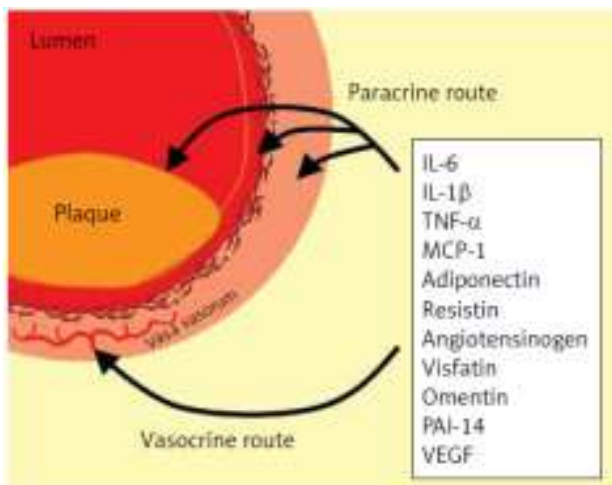

memfasilitasi sekresi dari molekul bioaktif ini bekerja dengan cara penyebaran melalui aliran darah mikrosirkulasi (vasokrin) maupun secara perkontinuatum (parakrin) karena kedekatan struktur tersebut. Seperti terlihat pada gambar 2 .

Gambar 2 Rute parakrin dan vasokrin dari molekul bioaktif yang dihasilkan oleh lemak epikardial terhadap arteri koroner (Nagy E et al) ${ }^{4}$ 


\section{PERAN PATOLOGIS JARINGAN LEMAK EPIKARDIAL PADA PENYAKIT JANTUNG KORONER}

Hingga saat ini peran sel lemak epikardial terhadap penyakit jantung koroner tidak sepenuhnya dimengerti, dipercaya melibatkan beberapa mekanisme yang kompleks, seperti stres oksidatif, disfungsi endotel, remodelling pembuluh darah, aktifasi makrofag, respon sistem imun alamiah, dan destabilisasi plak. Beberapa patomekanisme umum yang diyakini berperan besar seperti dijelaskan di bawah ini. ${ }^{13}$

\section{a) Infiltrasi dan diferensiasi makrofag pro inflamasi}

Jaringan lemak epikardial pasien penyakit jantung koroner ditemukan mengandung banyak makrofag fenotipe proinflamasi. Temuan ini diduga akibat terjadi polarisasi dari fenotipe makrofag antiinflamasi M2 ke fenotipe makrofag proinflamasi M1. Pada keadaan normal, jaringan lemak mengandung sel-sel imun yang didominasi oleh makrofag M2, dengan rasio M2:M1 adalah 4:1. Dalam jaringan lemak viseral banyak ditemukan sel $\mathrm{T} \mathrm{CD}^{+} /$ sel $T$ helper $2\left(T_{h} 2\right)$ yang mempunyai efek positif dalam memodulasi efek antiinflamasi dengan cara mengaktifasi dan rekruitmen makrofag antiinflamasi M2 melalui pelepasan sitokin sel $\mathrm{T}$ antiinflamasi seperti IL-4 dan IL-13 yang merangsang produksi sitokin antiinflamasi makrofag seperti IL-10. Selain itu, juga ditemukan peningkatan transkripsi beberapa gen antiinflmasi seperti gen yang mengkoding arginase-1, macrophage mannose receptor-1 dan IL-I receptor antagonist melalui jalur transkripsi factors peroxisome proliferator activated receptor- $\gamma$ (PPAR- $\gamma$ ) dan PPAR- $\delta$. Sebaliknya, pada keadaan obesitas abdominal, ditemukan peningkatan dari jumlah dan aktifitas sel $\mathrm{T} \mathrm{CD}{ }^{+/}$sel $\mathrm{T}$ helper $1\left(T_{h} 1\right)$ yang berperan dalam inisiasi dan rekruitmen makrofag proinflamasi M1 melalui pelepasan sitokin sel $\mathrm{T}$ proinflamasi seperti interferon- $\gamma$ (IFN- $\gamma$ ) yang merangsang produksi sitokin proinflamasi makrofag seperti tumor necrosis factor (TNF) dan IL-6. Sehingga secara fungsional, makrofag M2 berhubungan dengan fungsi pemeliharaan jaringan dan resolusi dari inflamasi sementara makrofag M1 berhubungan dengan proses inflamasi dan terjadinya resistensi insulin ${ }^{5,13,14}$, seperti terlihat dalam gambar $3 .^{15}$

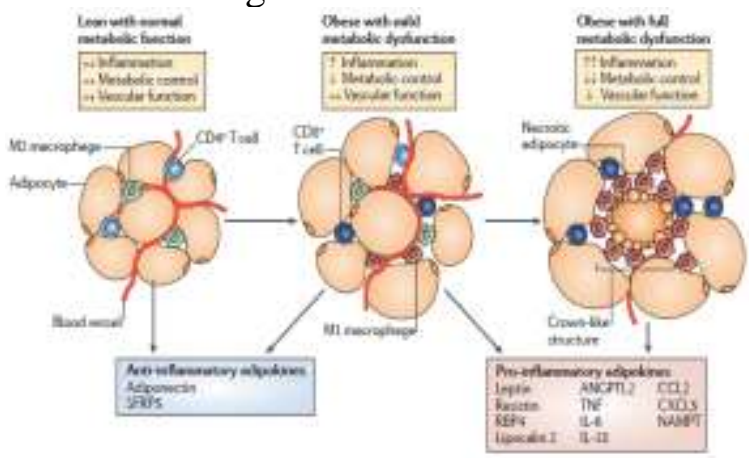

Gambar 3 Peran sel lemak epikardial pada kondisi fisiologis dan patologis (Ouchi $\mathrm{N}$ et al) ${ }^{14}$

Konsekuensinya, makrofag yang menginfiltrasi jaringan lemak epikardial ini membawa pada konsep bahwa disfungsi jaringan lemak adalah suatu proses inflamasi kronis dimana jaringan lemak melepaskan sitokin dan adipokin proinflamasi yang menyebabkan gangguan sensitifitas insulin dalam metabolisme jaringan. ${ }^{13}$

\section{b) Sekresi sitokin proinflamasi}

Mazurek dkk (2003) pertama kali melaporkan bahwa JLE pasien PJK mengandung lebih banyak (ekspresi gen dan sekresi protein) kemokin seperti MCP-1 dan beberapa sitokin proinflamasi IL-6, IL-1 $\beta$, and TNF- $\alpha$ dibandingkan dengan jaringan lemak subkutan. Selain itu ditemukan infiltrasi sel inflamasi lebih banyak termasuk makrofag dan sel mast pada JLE dibandingkan jaringan lemak subkutan. Kehadiran mediator-mediator inflamasi ini memberikan hipotesis bahwa inflamasi pembuluh darah, instabilitas plak melalui apoptosis (TNF- $\alpha$ ), dan neovaskularisasi 
(MCP-1), paparan sitokin proinflamasi serta oksidasi LDL menginduksi sel-sel inflamasi masuk ke dalam dinding arteri, yang lebih lanjut menyebabkan vasospasme koroner atau lesi intimal. Penelitian observasional ini menggambarkan bahwa molekul bioaktif dari jaringan perikoroner ini mungkin dapat mempengaruhi homeostasis arteri dan mendukung konsep "outside-to-inside" cellular cross-talk atau "vasocrine/paracrine signaling" (gambar 4).

\section{c) Peningkatan lipotoksisitas dan Reactive Oxygen Species (ROS)}

Peningkatan ketebalan lemak epikardial berhubungan dengan resistensi insulin, kondisi ini menyebabkan terjadi gangguan transfer aktif glukosa ke dalam sel miokard. Sehingga, penggunakan energi pada sel miokard dominan melalui pemecahan asam lemak. Kebutuhan yang tinggi akan energi ini, dominan dipenuhi melalui penggunaan asam lemak dari trigliserida yang disimpan pada sel lemak epikardial. Pada jaringan lemak, sumber energi lemak dalam bentuk trigliserida akan dipecah menjadi gliserol dan 3 asam lemak. Asam lemak dari sel ini, akan ditransfer ke dalam sel melalui pembuluh darah dengan cara berikatan dengan Lipoprotein, membentuk Low density lipoprotein (LDL). Peningkatan kadar LDL pada jaringan lemak viseral termasuk JLE ini meningkatkan lipotoksisitas pada miokard dan pembuluh darah koroner. LDL dapat menginfiltrasi langsung kedalam tunika intima dan tunika media pembuluh darah koroner dan menginisiasi proses aterosklerosis (gambar 4). Lebih lanjut, hasil akhir pemecahan asam lemak adalah benda keton, yang dapat menyebabkan cedera endotel dan lebih lanjut melalui penurunan $\mathrm{pH}$ akibat penumpukan keton sehingga memperberat progresifitas cedera endotel. ${ }^{13,16}$

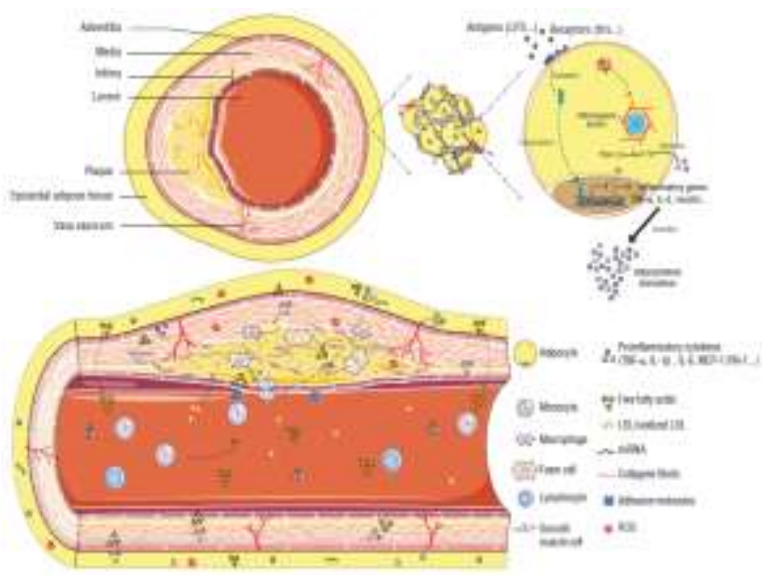

Gambar 4 Patomekanisme lemak epikadial dalam aterosklerosis (Gaborit Bee et al) ${ }^{13}$

Peningkatan ROS pada jaringan lemak terjadi akibat disfungsi mitokondria dan stres reticulum endoplasma. Secara biologik, yang termasuk sebagai ROS adalah hydrogen peroxide ( $\mathrm{H} 2 \mathrm{O} 2)$, hydroxyl radical $(\mathrm{OH} \cdot)$, and superoksida $(\mathrm{O} 2-)$. Namun ROS juga dihasilkan oleh selain mitokondria, seperti oksigen radikal yang berasal dari betaoksidasi peroksisomal asam lemak bebas, xanthine oxidase, oksidasi nicotinamide adenine dinucleotide phosphate (NADPH), enzim microsomal P450, metabolisme asam arakidonat, dan molekul pro-oksidan heme. Lebih lanjut, proses uncoupling dari endothelial nitric oxide synthase (eNOS) juga berkontribusi pada produksi ROS. Peningkatan ROS mengakibatkan peningkatan penghancuran NO dan mengurangi bioavailabilitasnya. Resultan peningkatan superoksida (O2-) dan peroksinitrit (ONOO-) memegang peranan penting dalam terjadinya peroksidasi lemak dan sel busa pada penyakit jantung koroner. Produksi yang berlebihan dari ROS menginduksi perubahan transkripsi DNA dan berakibat proliferasi selular dan berhentinya sejumlah besar signaling pathways seperti nuclear factor kappa beta $(\mathrm{NF}-\kappa \beta)$ yang menyebabkan fibrosis jaringan kardiovaskular, remodeling, dan disfungsional seperti gangguan relaksasi. 
Inflamasi dan stress oksidatif dapat mempromosikan terjadinya fibrosis dan kekakuan jaringan lemak, sebuat proses yang berhubungan dengan gangguan metabolisme insulin pada jaringan lemak, menyebabkan terjadinya resisten insulin dan sindroma metabolik. ${ }^{17}$

\section{d) Penurunan komposisi lemak coklat dari lemak epikardial}

Walaupun secara fungsional termasuk lemak putih, beberapa penelitian mengindikasikan bahwa jaringan lemak epikardial mengandung jaringan lemak coklat. Penelitian ini memperlihatkan kemungkinan dari kapasitas diferensiasi dari tipe sel lemak yang satu ke yang lain atau memang ada pengurangan komposisi lemak coklat pada jaringan lemak epikardial. Penelitian lain menemukan jaringan lemak epikardial mempunyai pola ekspresi gen "brown adipose tissue (BAT)-like" pada masa neonatus. Beralih ke masa infan jaringan lemak epikardial masih mempunyai proporsi pola ekspresi gen yang unik ini hingga sekitar $10 \%$, dan bertahan sampai dewasa. "BAT-like" gen ini mengekpresikan UCP-1, suatu protein yang spesifik mewakili aktifitas termoregulator dari lemak coklat, hal ini menjelaskan bagaimana kadar UCP-1 lebih tinggi pada jaringan lemak epikardial dibandingkan jaringan lemak lainnya. Berkurangnya atau menurunnya ekspresi UCP-1 memperberat infark miokard, fibrosis, remodelling jantung, sebaliknya kondisi negatif tersebut dapat di kurangi dengan transplantasi BAT pada jaringan lemak putih pada hewan coba. Sehingga muncul hipotesis bahwa proporsi lemak coklat pada jaringan lemak epikardial mempunyai peranan penting sebagai fungsi kardioproteksi, namun masih memerlukan penelitian lebih lanjut. ${ }^{5}$

\section{FAKTOR YANG MEMPENGARUHI DEPOSIT LEMAK EPIKARDIAL}

Jaringan lemak pada dasarnya mempunyai dua fungsi, yaitu fungsi endokrin dan fungsi penyimpanan energi. Kelebihan energi akan disimpan oleh tubuh dalam jaringan lemak subkutan, dan hal ini adalah kondisi yang normal. Bila terjadi gangguan pada fungsi jaringan lemak subkutan, maka kelebihan energi akan disimpan dalam bentuk lemak pada jaringan bukan lemak subkutan. Apabila kondisi ini telah terjadi, tubuh individu tersebut sudah mengalami perubahan profil metabolik. ${ }^{18}$

jaringan lemak subkutan yang mengalami disfungsi tidak mampu atau berkurang kemampuannya dalam proses normal penyimpanan kelebihan energi, sehingga kelebihan energi disimpan pada jaringan lemak viseral, dikenal dengan istilah spill over atau lipid overflow ectopic fat. Penumpukan lemak pada lemak viseral meningkatkan efek negatif proinflamasi yang berkibat buruk pada masing-masing organ viseralnya. ${ }^{17}$

Kondisi ini dipengaruhi oleh beberapa faktor diantaranya yaitu:

\section{Genetik}

Tebal lemak epikardial berbeda-beda disetiap etnis, diketahui etnis asia tenggara, asia selatan dan asia timur memiliki deposit lemak epikardial yang relatif rendah dibandingkan etnis kaukasia. Sementara etnis Jepang memiliki deposit lemak epikardial lebih tinggi dibandingkan ras kulit hitam Afriko-Amerika. Analisis genom pada 5487 ras Eropa pada penelitian Framingham Heart Study (FHS) dan Penelitian Multi Ethnic Study of Atherosclerosis (MESA) ditemukan lokus spesifik yakni unique locus 10198628 pada gen TRIB2 (tribbles homolog 2 gene) yang bertanggung jawab terhadap deposit lemak epikardial. ${ }^{13}$ Jermendy dkk melakukan penelitian nilai lemak epikardial, subkutan dan visceral yang dihitung melalui CT scan pada sampel saudara kembar, dan mendapatkan indikasi bahwa lemak epikardial memiliki hubungan genetik yang kuat. Dengan kontribusi faktor genetik 
secara keseluruhan (multi model fitting analysis) untuk lemak epikardial, lemak subkutan dan lemek abdominal adalah $80 \%$, $78 \%$ and $70 \%$ sementara faktor lingkungan berperan sekitar 20\%, 22\% and 30\%, secara berurutan. $^{19}$ Penderita kelainan genetik insulin-resistence hypertropic adipose tissue, defek pada jaringan lemak subkutan (LMNA genes linkes lypodistrophy), dimana terjadi keterbatasan dari kemampuan sel lemak untuk melakukan hiperplasia ketika kelebihan energi, terjadi spill over atau deposisi kelebihan energi pada tempattempat yang tidak semestinya seperti jantung, hepar, otot skeletal, pankreas, ginjal dan sebagainya. Hal ini didukung oleh temuan pada tikus coba, tikus kurus dengan profil lemak subkutan yang rendah dan lemak viseral yang tinggi sementara tikus gemuk dengan profil yang sebaliknya. Tikus gemuk memiliki profil metabolik yang sehat, dan ditemukan overekspresi adiponektin. Graft jaringan lemak subkutan sehat pada tikus kurus, memberikan hasil perbaikan profil metabolik. Terapi dengan peroxisome prolifator-activated receptor gamma agonist menginduksi pertumbuhan jaringan lemak subkutan melalui hiperplasia sel lemak subkutan, dan hal ini menurunkan deposit lemak ektopik dan memperbaiki sensitifitas insulin. ${ }^{18}$

\section{Faktor lingkungan}

Konsumsi kalori berlebih, gaya hidup yang kurang olahraga dapat memodulasi deposit lemak ektopik. Perokok memiliki lebih banyak deposit lemak viseral termasuk lemak abdominal dan epikardial dan lebih tinggi angka resistensi insulin. Diet tinggi fruktosa dapat menginduksi deposisi lemak viseral secara keseluruhan. ${ }^{18}$

\section{Epigenetik}

Pada penelitian terhadap tikus coba, ditemukan efek bahwa kondisi saat fetus seperti undernutrisi pada usia akhir gestasi menyebabkan peningkatan deposit lemak viseral. ${ }^{13}$

\section{TEORI PENYEBAB TERBENTUKNYA LEMAK EKTOPIK}

Seperti telah dijelaskan diatas, lemak ektopik adalah deposit lemak pada jaringan atau organ non lemak. Ada beberapa mekanisme potensial, diantaranya yaitu:

1. Hipotesis expendibilitas : disfungsi jaringan lemak subkutan

Kapasitas penyimpanan lemak pada jaringan lemak subkutan mempunyai batas, ketika batas ini terlampaui, maka kelebihan energi selanjutnya akan disimpan pada jaringan lemak viseral dan organ (spill over), bila telah terjadi hal seperti ini, telah terjadi resistensi insulin dan kumpulan kondisi patologis sindrom metabolik. Bukti yang mendukung adalah kondisi genetik LMNA genes linked lypodistrophy, tidak berkembangnya jaringan lemak subkutan, menyebabkan resisten insulin berat, hipertrigliseridemia, dan peningkatan deposisi lemak pada jantung dan hati. ${ }^{13}$

2. Fibrosis

Sel lemak dikelilingi oleh protein matriks ekstraselular (MES). Pada adipogenesis, baik pembentukan maupun ekspansi dari jaringan lemak, secara dramatis terjadi peningkatan dan remodelling MES. Hal ini terjadi untuk mengakomodasi pertumbuhan jaringan lemak. Pada jaringan lemak dengan gangguan metabolik, ditemukan fibrosis yang lebih banyak dibandingkan individu sehat. Ditandai dengan protein MES yang berlimpah, khususnya deposisi kolagen abnormal. ${ }^{13}$

Sepanjang proses obesitas terjadi remodelling, komposisi dan rigiditas dari MES yang mengganggu kemampuan ekspandibilitas jaringan lemak. Secara fisik membatasi hipertrofi dan hiperplasia adiposit sehingga memodulasi lipotoksisitas dan deposisi lemak ektopik Ekspansi jaringan lemak dengan cepat menemui keadaan hipoksia jaringan. Hipoksia menginduksi pelepasan H1F1a (hypoxia 
inducible factor-1 $\alpha), \quad$ adipokin proangiogenik, yang bertujuan untuk membentuk pembuluh darah guna mengatasi hipoksia. Karena proses lipogenesis terus berlangsung, peningkatan H1F1 $\alpha$ ini justru menginduksi gen-gen yang bertanggung jawab untuk terjadinya fibrosis, termasuk kolagen-kolagen dan enzim biosintesisnya, seperti LOX (Lysyl Oxidase). Kondisi ini berakibat meningkatnya jumlah dan komposisi MES menjadi abnormal, dan bertanggung jawab terjadinya fibrosis, yang lebih lanjut menjadi nekrosis adiposit. Adiposit yang nekrosis mengaktifasi dan menarik makrofag M1 yang seperti sudah diketahui menyebabkan inflamasi dan disfungsi metabolik. Disamping itu, H1F1 $\alpha$ dapat secara langsung menginduksi faktorfaktor proinflamasi, seperti IL6 dan MIF (Macrophag Inflamation Factors), yang lebih lanjut menyebabkan infiltrasi dan aktifasi makrofag M1. Interaksi antara preadiposit, makrofag dan sel ini menghasilkan komponen fibrotik, yang pada akhirnya menyebabkan berkurangnya kemampuan ekspansi dari jaringan lemak subkutan. $^{20}$

Kondisi ini didukung oleh penelitian pada hewan coba, ditemukan bahwa pemberian penghambat $\mathrm{H} 1 \mathrm{~F} 1 \alpha$ pada tikus coba yang obese dapat dengan efektif mencegah terjadinya fibrosis jaringan lemak. Penghambatan H1F1 $\alpha$ berhubungan dengan perbaikan profil metabolik, walaupun dalam diet tinggi lemak. ${ }^{20}$ Penelitian lain pada tikus coba, obes genetik dan karena diet. Dilakukan ablasi genetik kolagen VI (komponen protein paling banyak penyusun MES pada jaringan lemak dan bersifat relatif kaku). Tindakan ini menginduksi stabilitas MES berupa penurunan fibrosis jaringan lemak dan secara dramatis memperbaiki metabolisme lemak dan glukosa. Hal ini menunjukkan bahwa berkurangnya gen profibrosis dan kolagen VI pro fibrosis, memberi ruang adiposit untuk meningkatkan ukurannya tanpa batasan dari MES konstrain, mempermudah simpanan lemak dan menurunkan deposisi lemak ektopik dan pada jaringan bukan lemak. Hasil ini memberikan dugaan bahwa fibrosis jaringan lemak tampaknya menginduksi ganguan metabolik sistemik seperti juga fibrosis dijantung, hati, dan ginjal. Mempertahankan elastisitas MES, akan mempermudah jaringan lemak untuk ekspansi secara sehat, tanpa konsekuensi gangguan metabolik. ${ }^{13}$

Makrofag mempunyai peran penting pada fibrosis. Makrofag memproduksi sitokin TGF- $\beta 1$ (Transforming Growth Factor- $\beta 1$ ) yang mengaktifasi preadioposit secara langsung untuk berdiferensiasi menjadi myofibroblast-like phenothype sehingga mempromosikan terbentuknya fibrosis dalam jaringan lemak selama kondisi ekspansi jaringan lemak yang tidak sehat. $^{13,21}$ Sehingga diajukan teori bahwa adanya fibrosis pada jaringan lemak, mempromosikan terjadinya nekrosis pada sel lemak, menyebabkan terjadinya infiltrasi sel-sel imun untuk menghilangkan sel-sel debris, sehingga berlangsung low grade inflammation. Kondisi ini, disamping menjadi pencetus terjadinya deposit lemak ektopik, juga menjadi dasar terjadinya aterosklerosis termasuk pada arteri koroner bila proses tersebut berlangsung pada lemak epikardial. Karena faktor-faktor inflamasi tersebut dapat disebarkan secara vasokrin dan parakrin dari sel lemak ke arteri koroner.

\section{OBESITAS DAN LEMAK PIKARDIAL}

Obesitas adalah masalah klinis utama dalam kehidupan saat ini. Berdasarkan WHO tahun 2000 obesitas pada ras Asia Tenggara adalah bila index masa tubuh $>25$ $\mathrm{kg} / \mathrm{m}^{2}$. Obesitas sering berhubungan dengan beberapa penyakit seperti dyslipidemia, insulin resisten dan hipertensi yang dikenal sebagai sindrom metabolik. ${ }^{22}$ Menariknya, beberapa penelitian tidak menemukan 
korelasi antara index masa tubuh dan aterosklerosis koroner. Akan tetapi, pasien dengan lesi arteri koroner mempunyai volume lemak epikardial yang lebih tinggi dibandingkan dengan orang dengan normal koroner. ${ }^{16}$

Berdasarkan teori yang dikemukakan sebelumnya tentang spill over, jelas bahwa kelainan metabolik dan penyakit kardiovaskular tidak hanya dipengaruhi oleh obesitas yang didefenisikan berdasarkan index masa tubuh. Kelemahan indeks masa tubuh adalah tidak mencerminkan distribusi dari depot lemak pada tubuh. Sementara banyak penelitian epidemiologi besar, termasuk penelitian INTERHEART, menemukan bahwa obesitas sentral lebih berkorelasi kuat dengan resiko penyakit kardiovaskular daripada hanya obesitas berdasarkan indeks masa tubuh. ${ }^{23-25}$ Obesitas sentral ini dideskripsikan dengan data antropometri seperti lingkar perut, rasio pinggang-panggul, dan sebagainya berkorelasi kuat dengan penyakit kardiovaskular. ${ }^{24}$

Penelitian metaanalisis oleh Rabkin SW dkk didapatkan bahwa terdapat hubungan signifikan $(\mathrm{P}<0.00001)$ antara jaringan lemak epikardial dan IMT, atau lingkar pinggang atau jaringan lemak viseral. Korelasi antara jaringan lemak epikardial dan jaringan lemak viseral lebih tinggi dibandingkan korelasi antara jaringan lemak epikardial dan IMT. Secara keselurahan tebal lemak epikardial didapatkan lebih tinggi pada individu dengan sindroma metabolik dibandingkan individu dengan profil metabolik yang sehat $(7.5 \pm 0.1 \mathrm{~mm}$ (n $=427)$ vs $4.0 \pm 0.1 \mathrm{~mm}(\mathrm{n}=301))$. Jaringan lemak epikardial signifikan berhubungan dengan tekanan darah sistolik, kadar trigliserida, HDL, dan gulah darah puasa, namun kekuatan korelasi Jaringan lemak epikardial terhadap masing-masing variable ini masih kurang dari setengah kekuatan korelasi antara jaringan lemak epikardial terhadap IMT. Setelah Analisa multivariat ditemukan antara jaringan lemak epikardial dan sindrom metabolik independent terhadap IMT. ${ }^{26}$

\section{SIMPULAN}

Lemak epikardial merupakan bagian dari lemak viseral yang mempunyai peran lebih besar dalam proses aterosklerosis koroner karena kedekatan struktur diantara keduanya. Peran lemak epikardial dalam aterosklerosis koroner terjadi karena pergeseran fungsi fisiologis lemak epikardial ke arah patologis akibat dari disfungsi lemak subkutan dan dipengaruhi oleh berbagai faktor termasuk faktor genetik dan lingkungan. Peran lemak epikardial dalam patofisiologi penyakit jantung koroner meliputi mekanisme infiltrasi dan diferensiasi makrofag proinflamasi, sekresi sitokin proinflamasi, peningkatan lipolisis dan Reactive Oxygen Species (ROS), penurunan komposisi lemak coklat dari lemak epikardial.

\section{REFERENSI}

1. RISKESDAS. Riset Kesehatan Dasar (RISKESDAS) Badan Penelitian dan Pengembangan Kesehatan Kementrian Kesehatan Republik Indonesia Jakarta: Kementrian Kesehatan RI; 2013: 384.

2. Go AS, Mozaffarian D, Roger VL, Benjamin EJ, Berry JD, Borden WB, et al. Heart disease and stroke statistics--2013 update: a report from the American Heart Association. Circulation. 2013;127:e19.

3. Prasetya M, Oenzil F and Karani Y. Hubungan Indeks Masa Tubuh dan Lingkar Perut dengan Low Density Lipoprotein pada Pasien Penyakit Jantung Koroner di Poliklinik Jantung RSUP Dr. M. Djamil Padang. Jurnal Kesehatan Andalas. 2015;4:737-742.

4. Nagy E, Jermendy AL, Merkely B and MaurovichHorvat $P$. Clinical importance of epicardial adipose tissue. Archieve of Medical Science. 2016;13:858.

5. Patel VB, Shah S, Verma S and Oudit GY. Epicardial adipose tissue as a metabolic transducer: role in heart failure and coronary artery disease. Heart Failure Reviews. 2017:4-8. 
6. Sherwood L. Human Physiology: From Cells to Systems. In: L. Sherwood, ed. Energy Balance and Temperature Regulation. 9 ed. Boston: Cengage Learning; 2016: 618-637.

7. Rietdorf $\mathrm{K}$ and MacQueen $\mathrm{H}$. Investigating interactions between epicardial adipose tissue and cardiac myocytes: what can we learn from different approaches? British Journal of Pharmacology. 2016; 174 3542-3560.

8. Sarantopoulos CN, Banyard DA, Ziegler ME, Sun $B$, Shaterian $A$ and Widgerow AD. Elucidating the Preadipocyte and Its Role in Adipocyte Formation: a Comprehensive Review. Stem Cell Review and Report 2017:1-16.

9. lacobellis G and Sharma AM. Epicardial Adipose Tissue As New Cardio-Metabolic Risk Marker and Potential Therapeutic Target in the Metabolic Syndrome. Current Pharmaceutical Design. 2007;13:2180-2184.

10. Wu Y, Zhang A, Hamilton DJ and Deng T. Epicardial Fat in the Maintanance of Cardiovascular Health. Methodist DeBakey Cardiovascular Journal. 2017;13:20-24.

11. Turer At and Scherer PE. Adiponectin: mechanistic insights and clinical implications. Diabetologia 2012;55:2319-2326.

12. lacobellis $G$ and Bianco AC. Epicardial adipose tissue: emerging physiological, pathophysiological and clinical features. Trends in Endocrinology and Metabolism. 2011;22:450-457.

13. Gaborit Bee, Sengenes C, Ancel P, Jacquier A and Dutour A. Role of Epicardial Adipose Tissue in Health and Disease: A Matter of Fat? Comprehensive Physiology. 2017;11:1060-69.

14. Ouchi N, Parker JL, Lugus JJ and Walsh K. focus on metabolism and immunology: Adipokines in inflammation and metabolic disease. Immunology. 2011;11:84-94.

15. Vianello E, Dozio E, Arnaboldi F, Gnes $M$, Marazzi, Martinelli C, et al. Epicardial adipocyte hypertrophy: Association with M1-polarization and toll-like receptor pathways in coronary artery disease patients. Nutrition, Metabolism \& Cardiovascular Diseases 2016;26:246-253.

16. Matloch Z, Kotulak T and Haluzik M. The role of epicardial adipose tissue in heart disease. Physiology Research. 2016;65:23-32.

17. Jia G, Jia $Y$ and Sowers JR. Contribution of Maladaptive Adipose Tissue Expansion to
Development of Cardiovascular Disease. Comprehensive Physiology. 2017;7:253-262.

18. Despre's J-P. Body Fat Dlstribution and Risk of Cardiovascular Disease: An Update. Circulation. 2012;126:1301-1313.

19. Jermendy AL, Kolossvary M, Drobni, Tarnoki, Tarnoki, Karady J, et al. Assessing genetic and environmental influences on epicardial and abdominal adipose tissue quantities: A classical twin study. International Journal of Obesity accepted article preview 30 August 2017; doi: 10.1038/ijo.2017.212.:1-31.

20. Sun K, Tordjman J, Clémen K and Scherer PE. Fibrosis and Adipose Tissue Dysfunction. Cellular Metabolism 2013;18:470-477.

21. Barnes JL and Gorin Y. MYofibroblast DIfferentiation During Fibrosis: Role of $\mathrm{NAD}(\mathrm{P}) \mathrm{H}$ oxidases. Kidney International. 2011;79:944-956.

22. International Diabetes Federation. The IDF consensus worldwide definition of the metabolic syndrome. 2005:1-7.

23. Zhang C, Rexrode KM, Dam RMv, Li TY and Hu FB. Abdominal Obesity and the Risk of All-Cause, Cardiovascular, and Cancer Mortality. Circulation. 2008;117: 1658-67.

24. Yusuf S, Hawken S, Ôunpuu S, Dans T, Avezum A, Lanas $F$, et al. Effect of potentially modifiable risk factors associated with myocardial infarction in 52 countries (the INTERHEART study): casecontrol study. Lancet. 2004;364:937-52.

25. Gelber RP, Gaziano M, Orav J, Manson, Buring JE and Kurth T. Measures of obesity and cardiovascular risk among men and women. Journal of American College of Cardiology. 2008;52:605-615

26. Rabkin SW. The Relationship Between Epicardial Fat and Indices of Obesity and the Metabolic Syndrome: A Systematic Review and MetaAnalysis. METABOLIC SYNDROME AND RELATED DISORDERS. 2013;12:31-42. 